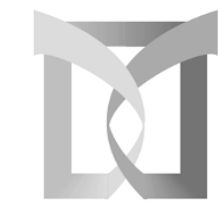

Sidney Kimmel

Cancer Center

$$
\text { atrianto } \overline{\operatorname{SIARP}}
$$

presents

\title{
Ninth International Conference on
}

\section{GENE THERAPY OF CANCER}

December 7-9, 2000 San Diego, California

Conference Directors

Robert E. Sobol, MD Kevin J. Scanlon, PhD

Ivor Royston, MD

Conference Faculty

Estuardo Aguilar-Cordova, PhD

Albert B. Deisseroth, MD, PhD

Evan Hersh, MD

Thomas Kipps, MD

David H. Kirn, MD

Frederick L. Moolten, MD
Jack Roth, MD

Yanina Rozenberg, PhD

Friedrich Schuening, MD

Jonathan Simons, MD

Richard Vile, MD, PhD

Harold von Melchner, MD

Robert Warren, MD 
Ninth International Conference on

GENE THERAPY OF CANCER

\section{Acknowledgements}

We would like to express our appreciation to the following organizations for their support of this conference. Their financial contributions help to make this conference possible.

Supported in part by a grant from the National Cancer Institute

Corporate Sponsors:

Althea Technologies

Aventis

Berlex

BioReliance

Canji, Inc.

Schering-Plough Oncology/Biotechnology

Cell Genesys

Introgen Therapeutics, Inc.

InvivoGen

Nature Publishing Group

Vical, Inc.

Corporate Supporters:

GenVec

Hoffman-La Roche Inc.

Ligand Pharmaceuticals Incorporated

Miltenyi Biotec, Inc.

Targeted Genetics Corporation

W. B. Saunders 


\title{
Ninth International Conference on \\ GENE THERAPY OF CANCER
}

\section{Final Program}

Abstract No.

\section{Wednesday, December 6}

\author{
5:00 - 7:00 pm Early Conference Registration
}

\section{Thursday, December 7}

6:45 am Registration and Coffee

8:00 am Welcome and Announcements

Robert E. Sobol, $M D$

Kevin J. Scanlon, PhD and Ivor Royston, MD

Session I: Tumor Suppressors/Apoptosis

Chair: Jack Roth, MD, UTMD Anderson Cancer Center, Houston, TX

\section{Mini-Symposium: p53 Gene Therapy}

8:15 am Integration of Gene Replacement with Multimodality Cancer Treatment O-1 Jack Roth, MD UTMD Anderson Cancer Center, Houston, TX

$8: 45 \mathrm{am}$

$9: 15 \mathrm{am}$

$9: 30$ am

$9: 45 \mathrm{am}$
Regional Delivery of rAdp53 for Liver Tumors Robert Warren, MD

University of California, San Francisco

Multi-Dose Intraperitoneal (IP) RAD/P53 (SCH58500) Gene Replacement Combined with Platinum-Based Chemotherapy in Heavily Pretreated Recurrent Ovarian Cancer is Associated with Prolonged Survival Richard E. Buller, MD

University of Iowa Hospitals \& Clinics, Iowa City

Adenovirus-Mediated Wild Type p53 Gene Transfer in Patients Receiving Chemotherapy for Advanced Non-Small Cell Lung Cancer: Results of a Multicenter Phase II Study Martin Schuler, MD

La Jolla Institute for Allergy \& Immunology, CA

Aerosol Delivery of PEI-p53 Complexes for Treatment of Metastatic Lung Cancer Charles L. Densmore, PhD

Baylor College of Medicine, Houston, TX 
10:00 am Coffee Break, Visit Exhibits, Poster Viewing

10:30 am Ad-mda7: A Novel, Potent and Broad-Spectrum Anti-Tumor Agent Introgen Therapeutics, Inc., Houston, TX

10:45 am Prostate Cancer Gene Therapy Using Recombinant Adenovirus $\mathrm{Yi} \mathrm{Lu}, \mathrm{PhD}$

University of Tennessee, Memphis

11:00 am Retroviral-Mediated Re-Expression of the Transcription Factor EGR-1 in Human

Human Gene Therapy Research Institute, Des Moines, IA

11:30 am Local Anti-Angiogenic Therapy of Gliomas Delivered by Cells

Encapsulated in Alginate: A Promising New Therapeutic Concept Tracy-Ann Read University of Bergen, Norway

11:45 am Evaluation of Endostatin Anti-Angiogenesis Gene Therapy In Vitro and In Vivo Loretta Nielsen, PhD Schering-Plough Research Institute, Kenilworth, NJ

\title{
Session II: Vector Systems
}

Chair: David H. Kirn, MD, ICRF, Imperial College School of Medicine, London, UK

\section{Mini-Symposium: Adenoviral Vectors}

\author{
1:15 pm Replication - Selective Adenoviruses for the Treatment of Cancer \\ David H. Kirn, MD \\ ICRF, Imperial College School of Medicine, London, UK \\ 1:35 pm Phase I Dose Escalation Trial of Intravenous (IV) Infusion of CI-1042 \\ (ONYX-015) in Patients with Refractory Cancer \\ John Nemunaitis, $M D$ \\ US Oncology, Dallas, TX
1:50 pm Adenovirus Shedding: Problems Related to Patient Containment. Lessons From IGR Experience Bernard Escudier, MD
Institute Gustave Roussy, Villejuif, France


Abstract No.

2:05 pm

$2: 20 \mathrm{pm}$

$2: 35 \mathrm{pm}$

$2: 55 \mathrm{pm}$
Anti-Tumor Synergy of CV787, a Prostate Cancer-Specific Adenovirus, and Paclitaxel and Docetaxel De-Chao $\mathrm{Yu}, \mathrm{PhD}$

Calydon, Inc., Sunnyvale, $C A$

p53-Regulated Selectively Replicating Adenovirus Vectors

Murali Ramachandra, PhD

Canji Inc., San Diego, CA

Adenoviral-Models for Targeting and Tumor Specific Replication Competency

Albert B. Deisseroth, MD, PhD

Yale University School of Medicine, Brandford, CT

Coffee Break, Visit Exhibits, Poster Viewing
O-29

O-30

O-31

O-32

Self-Deleting Suicide Vectors (SDSV): Selective Killing of p53-Deficient Cancer Cells Harald von Melchner, MD

University of Frankfurt Medical School, Germany

3:30 pm The Development of a Novel Epstein Barr Virus-Targeted Adenoviral Vector of Cancer Gene Therapy

O-33

Fei-Fei Liu, MD

Ontario Cancer Institute, Toronto, Canada

$3: 45 \mathrm{pm}$

Transcriptional Targeting in Cancer Gene Therapy: Lessons from Gliomas and Thyroid Tumors

O-34

Giorgio Palù, PhD

University of Padova, Italy

4:00 pm

Tissue Regulated Expression of FasL as a Gene Therapy

James S. Norris, PhD

Medical University of South Carolina, Charleston

\section{Receptor Targeting}

$4: 15 \mathrm{pm}$

Towards Targeted Alternative Gene Delivery (TAGD)

Yanina Rozenberg, PhD

University of Southern California, Los Angeles

$4: 35 \mathrm{pm}$

Histidylated Oligolysine Conjugated to a Tumor-Homing RGD Motif as a Novel Non-Viral Vector of Gene Therapy for Advanced Solid Cancers

Yuji Aoki, MD, PhD

Shinshu University School of Medicine, Nagano, Japan

4:50 pm EGF-Targeted Phage Gene Transfer to Human Carcinoma

Cells is Enhanced by Camptothecin

Michael A. Burg, PhD

Selective Genetics, San Diego, CA

5:05 pm Wine \& Cheese Reception

6:30 pm Pharmaceutical Speakers Forum

Safety Profile of DNA Vaccines in Clinical Studies: The Vical Inc. Experience

O-96

John Gutheil, MD

Vical Inc., San Diego, CA 
Replication Competent Herpes Simplex Viruses: Preclinical and Clinical Development Jeffrey Ostrove

NeuroVir, Inc., San Diego, CA

7:30 pm Adjourn

\section{Friday, December 8}

7:00 am Coffee, Visit Exhibits, Poster Viewing

Session III: Hematopoietic Gene Transfer/Hematopoietic Cancers

Chair: Friedrich Schuening, MD, Vanderbilt University, Nashville, TN

8:00 am Gene Transfer into Canine and Human Hematopoietic Stem Cells

O-52

Friedrich Schuening, $M D$

Vanderbilt University, Nashville, TN

8:30 am Gene Therapy for Hematologic Malignancies

O-53

Thomas Kipps, $M D$, PhD

University of California, San Diego

9:00 am Induction of Anti-Tumor Response and Control of Graft Versus Host Disease by

O-54

HSVtk-Transduced Allogeneic Donor Lymphocytes

Tatiana Seregina, PhD

Human Gene Therapy Research Institute, Des Moines, IA

9:15 am Cytotoxic T Lymphocyte Therapy for EBV+ Hodgkin Disease

O-55

Laura K. Aguilar, MD, PhD

Harvard Gene Therapy Initiative, Boston, MA

9:30 am Mesenchymal Stem Cells (MSC) to Deliver Localized Regulated

O-56

Interferon-Alpha 2B (INF $\alpha)$ : A Novel CML Therapy

Frank C. Marini III

UT MD Anderson Cancer Center, Houston, TX

9:45 am Ras Activity as a Marker for Application of Oncolytic Herpes Simplex Virus-1, R3616,

O-57

in Hematopoietic Malignancies: Preferential Infection of Raji but not Jurkat of Daudi Cells By R3616

Faris Farassati, PhD

University of Calgary Cancer Biology Research Group, Alberta, Canada

10:00 am Coffee Break, Visit Exhibits, Poster Viewing

Session IV: Suicide Gene Therapy

Chair: Estuardo Aguilar-Cordova, PhD, Harvard, Boston, MA

10:30 am Novel Suicide Gene Therapy Approaches

O-58

Estuardo Aguilar-Cordova, PhD

Harvard Gene Therapy Institute, Boston, MA 
11:00 am

$11: 15$ am

$11: 45$ am

$12: 00 \mathrm{pm}$

$12: 15 \mathrm{pm}$

$12: 30 \mathrm{pm}$

$12: 45 \mathrm{pm}$

1:00 pm

2:00 pm
Phase I Study of Replication-Competent Adenovirus-Mediated Double Suicide Gene Therapy for Local Recurrence of Prostate Cancer After Definitive Radiation Therapy

Svend O. Freytag

Henry Ford Health System, Detroit, MI

Creation of Stable Suicide Functions by Combining Suicide Gene Transduction with

Endogenous Gene Loss

Frederick L. Moolten, MD

Edith Nourse Rogers Memorial Veterans Hospital, Bedford, MA

VDEPT Methods of Purging Neuroblastoma Cells from Hematopoietic

O-61/62

Cells Prior to Autologous Stem Cell Rescue

Mary Danks, PhD

St. Jude Children's Research Hospital, Memphis, TN

Horseradish Peroxidase (HRP)/Indole-3-Acetic Acid (IAA) in GDEPT: Use of IAA and Analogues in Oxic and Anoxic Tumor Conditions

Olga Greco, MS

Gray Laboratory Cancer Research Trust, Northwood, Middlesex, UK

Apoptosis of Cancer Cells Induced by Methionine $\gamma$-Lyase

Cleavage of Selenomethionine: A Novel Approach to Gene Therapy

Robert M. Hoffman, PhD

Anticancer, Inc., San Diego, CA

Characterization of the Cyclooxygenase-2 Promoter in an Adenoviral Vector and its

Application for the Mitigation of Toxicity in Suicide Gene Therapy of

Gastrointestinal Cancers

Masato Yamamoto, PhD

University of Alabama, Birmingham

Radiation-Activated Gene Therapy Vectors for Cancer

Simon D. Scott, PhD

Gray Laboratory Cancer Research Trust, Northwood, Middlesex, UK

Lunch (on your own)

Poster Viewing

\section{Session V: Poster/Discussion (Simultaneous Sessions)}

\section{3:00-5:30 pm 1. Tumor Suppressors/Apoptosis/Antisense-Ribozymes} Chair: Kevin Scanlon, PhD, Keck Graduate Institute, Claremont, CA

Mini-Symposium: Antisense/Ribozymes

Comparison of Feasibility of the Drug-Delivery Systems Between the Recombinant

Adenovirus and the Liposome Using MARCO for the Treatment of Leukemias Naoki Shirafuji, MD

Teikyo University School of Medicine, Tokyo, Japan

Adenovirus-Mediated Ribozyme Against Mutant K-ras Transcripts Induces Apoptosis and

Growth Suppression of Pancreatic Cancer

Hiroshi Kijima, PhD

Tokai University School of Medicine, Kanagawa, Japan 
Abstract No.

Modulation of Cisplatin Resistance in Ovarian Carcinoma Cells by Hammerhead

PD-14

Ribozymes Directed Against the MRNA Encoding the ABC-Transpoter

cMOAT/MRP2/ABCC2

Hermann Lage, PhD

Humboldt University, Berlin, Germany

A Selection System for Identifying Ribozyme Target Cleavage Site Accessibility

PD-15

Wei-Hua Pan

Pennsylvania State University, Hershey

Antisense Gene Therapy Targeting Sex Hormone-Binding Globulin (shbg)

PD-16

Gene in Human Breast Cancer

Yoichi Murayama, PhD

Tokyo Medical \& Dental University, Japan

The Human Polyomavirus BK (BKV) and Neuroblastoma Mechanisms of

PD-17

Action and Possible Strategy for Treatment

John Inge Johnsen, PhD

University of Tromso, Norway

Tumor Suppressors/Apoptosis

Growth Inhibitory Effect of Adenovirus-p27 Gene Transfer On Head and Neck

PD-18

Squamous Cell Carcinoma Cell Lines

Seok-Woo Park, MD

Seoul National University College of Medicine, Korea

An Adenovirus Expressing Mutant p27 Showed More Potent Antitumor

Effects than Adenovirus-Wild p27

Choon-Taek Lee, MD

Seoul National University College of Medicine, Korea

Combined Vaccinia Virus-Mediated Antitumor Gene Therapy

PD-20

with p53, IL-2 and IL-12 in a Glioma Model

Istvan Fodor, PhD

Loma Linda University, $C A$

Nonsecreted Interferon Delivery by an Adenoviral Vector Confers Antiproliferative

Properties and Causes Suppression of Tumor Growth

C.M. Iqbal Ahmed

Canji, Inc., San Diego, CA

Gene Transfer of Caspase-3 Restores Sensitivity for Drug-Inducated

PD-22

Apoptosis in Breast Cancer Cells With Acquired Drug Resistance

Peter Daniel

Humboldt University, Berlin, Germany

3:00-5:30 pm

\section{Vector Systems}

Chair: Harold von Melchner, MD,

University of Frankfurt Medical School, Frankfurt, Germany

Mini-Symposium: CAR Receptors 
Abstract No.

Biodistribution of Two Modified Ad5 Adenovirus Vectors (Adv) in Mice, the Enhanced Infection

PD-40 AdpK7, and the Fiber Deleted AD5 $\Delta$ F: Ablation of Both the Fiber/CAR and Integrin/Penton Interactions is Necessary to Block Infection

Frank C. Marini, PhD

UT MD Anderson Cancer Center, Houston, TX

The Expression of the Human Coxsackie and Adenovirus Receptor (CAR) Depends

PD-41 on the Three-Dimensional Organization of Epithelial Cells

Mario Anders, MD

University of California, San Francisco

Reduced Expression of Cosackievirus and Adenovirus Receptor (CAR) in Tumor Tissue in

Comparison to Normal Epithelium from Head and Neck Squamous Cell Carcinoma Patients Youn Suk Jee

Seoul National University College of Medicine, Korea

In-Vivo Binding to CAR of In-111 and I-131 Labeled Adenoviral Vectors of Varying Molecular Size Suresh C. Srivastava, PhD

Brookhaven National Laboratory, Upton, $N Y$

Vector Systems

Intraperitoneal (IP) Adenovirus-Mediated Transgene Expression is

PD-44

Enhanced by the Use of Icodextrin Delivery Solution

Heidrun Engler, $P h D$

Canji, Inc., San Diego, CA

Replicating Adenoviral Vectors Persist in Tumor Xenographs for up to 100 Days but

PD-45

Viral Spread is Insufficient to Support Tumor Eradication

Harald Sauthoff, $M D$

New York University, New York, NY

Transduction Efficiency and Kinetics of Recombinant Adeno-Associated Viral (rAAV)

PD-46

Vectors into Human Tumor Cells

Per Øyvind Enger, MD

University of Bergen, Norway

New Amplified Inducible Gene Expression Vectors

PD-47

Tom Tsang, PhD

University of Arizona, Tucson

High Efficiency Transgene Delivery and Expression in Growing Hair Shafts

PD-48

Robert M. Hoffman, PhD

Anticancer, Inc., San Diego, CA

Efficient Transfer of Human MDR1 cDNA or GFP into Hematopoetic Cells Expressing

PD-49

MHC Class I Using an SV40 In-Vitro Packaging Delivery System

Chava Kimchi-Sarfaty, $P h D$

NCI, Bethesda, MD

3:00-5:30 pm

\section{Suicide Gene Therapy}

Chair: Frederick L. Moolten, MD,

Edith Nourse Rogers Memorial Veterans Hospital, Bedford, MA

Development of a Dual Suicide miniEBV Vector for

PD-67

Episomal Gene Therapy of B-Cell Lymphomas

Jianlong Wang

University of North Carolina, Chapel Hill

Cancer Gene Therapy, Vol 7, No 12, 2000 
Abstract No.

A Novel Gene Therapy System Utilizing an Enzyme Activated Anthracycline

PD-68

Prodrug and Adenoviral Transfer Of Betaglucuronidase and Bax

Imran T. Mohuiddin, MD

UT MD Anderson Cancer Center, Houston, TX

Expression of Herpes Simplex Virus-Thymidine Kinase Gene

Controlled by a Promoter Region of the Midkine Gene Confers

Selective Cytotoxicity to Ganciclovir in Human Carcinoma Cells

Minoru Tomizawa, PhD

Chiba University School of Medicine, Japan

In Vivo Surgical Resection Plus Adjuvant Gene

PD-70

Therapy in The Treatment of Mammary and Prostate Cancer

Steve Sukin, MD

Baylor College of Medicine, Houston, TX

Bystander-Mediated Regression of Murine Neuroblastoma Via

PD-69

Retroviral Transfer of the HSV-TK Gene

Hyung-Sang Cho, MD

Hallym University College of Medicine, Seoul, Korea

Suicide Gene Therapy Approaches for Prostate Cancer: Potential Synergy with Radiotherapy

Ruth Foley, BA

St. James Hospital, Dublin, Ireland

3:00-5:30 pm

\section{ImmunoGene/Hematopoietic Gene Transfer} Chair: Thomas Kipps, MD, University of California, San Diego

Mini-Symposium: Dendritic Cell Vaccines

Cancer Immunotherapy of Interleukin-10 Gene Delivery with

Direct Injection of AdV-IL-10 or Genetically Modified Dendritic Cells

Seon-Hee Kim, PhD

University of Pittsburgh, PA

CD40 Crosslinking Bypasses the Absolute Requirement For CD4 Cells

PD-88

After Immunization with Melanoma Antigen Gene-Modified Dendritic Cells Antoni Ribas, $M D$

University of California, Los Angeles

Effect of Intratumoral Injection of Dendritic Cells Transduced With IL-2

Gene by Recombinant Adenovirus Vector on Tumor Growth

Yoshio Gunji, MD

Chiba University School of Medicine, Japan

Retrovirus-Mediated Gene Transfer of Prostate Specific Antigen (PSA) into

Dendritic Cell Precursors for the Immunotherapy of Prostate Cancer

Gangjian Qin, MD, University of Illinois, Chicago

ImmunoGene Therapy/Hematopoietic Gene Transfer

ICAM-1 Gene Therapy for the Lymph Node Metastasis and the Peritoneal

PD-91

Metastasis of Human Scirrhous Gastric Carcinoma

Tanaka Hiroaki

Osaka City University Medical School, Japan 
Abstract No.

Modulation of Host Immunosurveillance of Tumors by Abrogating TGF- $\beta$

PD-92

Signaling in Lymphocytes

Ali H. Shah

Northwestern University Medical School, Chicago, IL

Successful Generation of Autologous GMCSF-Modified Cancer Vaccines (GVAX $\left.{ }^{\circledR}\right)$ in

PD-93

Subjects with Non-Small Cell Lung Cancer (NSCLC) Using Adenoviral Vectors

Philip Maples

US Oncology, Dallas, TX

6:00 pm Reception

$7: 30 \mathrm{pm} \quad$ Adjourn

\section{Saturday, December 9}

7:30 am Coffee, Visit Exhibits, Poster Viewing

Session VI: ImmunoGene Therapy

Chair: Jonathan Simons, MD, Emory University, Atlanta, GA

\section{Mini-Symposium: GM-CSF Gene Therapy}

\begin{tabular}{|c|c|c|}
\hline 8:00 am & $\begin{array}{l}\text { Clinical and Immunologic Activity of Ex Vivo GM-CSF Gene Transduced Prostate Cancer Vaccines } \\
\text { Jonathan Simons, MD } \\
\text { Emory University, Atlanta, GA }\end{array}$ & O-74 \\
\hline $8: 30 \mathrm{am}$ & $\begin{array}{l}\text { Intratumoral Recombinant GM-CSF Encoding Vaccinia } \\
\text { Virus as Gene Therapy in Patients with Cutaneous Melanoma } \\
\text { Edmund C. Lattime, PhD } \\
\text { UMDJ-Robert Wood Johnson Medical School, New Brunswick, NJ }\end{array}$ & O-75 \\
\hline $8: 45 \mathrm{am}$ & $\begin{array}{l}\text { Tumor Cells Expressing Membrane Macrophage Colony Stimulating Factor (mM-CSF) } \\
\text { Leads to In Vivo Tumor Rejection and Immunity Against the Parental Tumor } \\
\text { Cells: Lessons Learned from Three Different Tumor Models } \\
\text { Martin R. Jadus, PhD } \\
\text { Veterans Affairs Medical Center, Long Beach, CA }\end{array}$ & O-76 \\
\hline 9:00 am & $\begin{array}{l}\text { Non-Viable Tumor GM-CSF Vaccine Cells Inhibit } \\
\text { the Generation of Anti-Tumor Immunity } \\
\text { Annie-Chen Tran } \\
\text { Cell Genesys, Inc., Foster City, CA }\end{array}$ & O-77 \\
\hline $9: 15 \mathrm{am}$ & $\begin{array}{l}\text { Intra-Tumoral Transfer of the HLA-B7 and IL-2 Genes for Cancer Therapy } \\
\text { Evan Hersh, } M D \\
\text { Arizona Cancer Center, Tucson }\end{array}$ & O-78 \\
\hline $9: 45 \mathrm{am}$ & Coffee Break, Visit Exhibits, Poster Viewing & \\
\hline 10:00 am & $\begin{array}{l}\text { Combination Gene Therapy with IL- } 12 \text { and IFN- } \alpha \text { Induces a Synergistic Anti- } \\
\text { Tumor Response Against Established Colon and Renal Cell Carcinoma } \\
\text { Federica Pericle } \\
\text { Valentis, Inc., The Woodlands, TX }\end{array}$ & O-79 \\
\hline
\end{tabular}


Abstract No.

10:15 am Localized pGL1-TNF- $\alpha$ Gene Therapy and Modulation of Effector O-80

Cell Populations in Athymic Mice with C6 Brain Tumor

Daila S. Gridley, PhD

Loma Linda University, $C A$

10:30 am Intratumoral Delivery of Interferon- $\delta$ cDNA with an Adenoviral Vector in

O-81

Combination with Systemic Chemotherapy: Pre-Clinical Studies in Murine Models

Philippe Slos, PhD

Transgene SA, Strasbourg Cedex France

10:45 am Gene Delivery of Fusogenic Proteins to Generate Local and Immune-Mediated Tumor Rejection

Richard Vile, $M D, P h D$

Mayo Foundation, Rochester, $M N$

11:15 am Protective Immunity is Induced in the Mice Inoculated with Murine Lung Carcinoma

Cells Expressing Membrane-Type Fas Ligand but not Soluble Fas Ligand

Masatoshi Tagawa, PhD

Chiba Cancer Center Research Institute, Japan

11:30 am DNA Vaccination Prevents and/or Delays Carcinoma Development of Papillomavirus-

O-84

Induced Skin Papillomas on Rabbits

Ricai Han, PhD

Pennsylvania State University College of Medicine, Hershey

11:45 am

SP1017- A Non-Ionic Block Copolymer-Based Gene Delivery System that Enhances Anticancer Activity

of Therapeutic DNA Vaccines by Attracting Dendritic Cells into the Transgene Expression Sites

Pierre Lemieux, PhD, Supratek Pharm, Inc., Quebec, Canada

12:00 pm Treatment of Mice with Complexes of Cationic Lipid and Non-Coding pDNA Induces Potent CD8 ${ }^{+}$

O-86

T-Cell Activity Resulting in Rejection of Solid Tumors and Distal Metastases

William M. Siders, PhD

Genzyme Molecular Oncology, Framingham, MA

$12: 15 \mathrm{pm}$

Closing Remarks

$12: 30 \mathrm{pm}$

Final Adjournment 